\title{
A Cautionary Tale: The 'New' Medical Tourism Industry in Argentina
}

\author{
Cecilia Vindrola-Padros
}

There are great surgeries all over the world, and there are cheap destinations. Argentina combines the two (Nwosu-Hope 2010: 2).

Argentina, already a popular player in the medical tourism industry, will continue to experience a rapid expansion in the delivery of services to foreign patients if government strategies go as planned. In 2011, a group of government ministries including Tourism and Health launched a new initiative to increase tenfold the number of yearly medical tourists. Promotional material depicting Argentina as 'The New Medical Tourism Mecca' has been disseminated across the media (Nwosu-Hope 2010), but government strategies for monitoring and regulating this new influx of foreign patients have not been made available. Theoretically, this initiative seeks to improve the health conditions of both foreign and local patients. However, in practice this may mean an already overburdened healthcare system will have to adapt to suit the needs of foreign, short-term, medical tourists mainly traveling for elective procedures, potentially at the expense of local patients.

Argentina currently experiences internal movements of patients due to the centralisation of medical facilities and personnel in the capital of Buenos Aires. Furthermore, Argentina's universal model

Somatechnics 5.1 (2015): 69-87

DOI: 10.3366/soma.2015.0148

(C) Edinburgh University Press and the Contributor. The online version of this article is published as Open Access under the terms of the Creative Commons Attribution-Non-Commercial Licence (http://www. creativecommons.org/licenses/by-nc/3.0/) which permits non-commercial use, distribution and reproduction provided the original work is cited. For commercial re-use, please contact permissions@eup.ed.ac.uk.

www.euppublishing.com/journal/soma 
of healthcare and open immigration policies make it a popular destination for people from neighbouring countries requiring free medical treatment. The flows of foreign patients and local migrating patients interact to create a complex system of medical tourism, posing ethical and legal challenges in the distribution of scarce resources and regulation of medical care.

The aim of this article is to discuss the ethical issues that will likely emerge if Argentina achieves its goal of becoming an international medical tourism destination. ${ }^{1}$ In this article I analyse the process of Argentine expansion within this billion-dollar industry in relation to the challenges currently facing its health care system. When macrolevel phenomena such as the international trade in health services are explored from a micro-level, site specific lens, complex internal dynamics are brought to light fuelling academic discussions on health equity and the regulation of medical practice.

\section{Medical tourism and the destination country}

Destination countries such as India, Malaysia, and Thailand have praised the benefits of medical tourism, ${ }^{2}$ arguing that this type of enterprise generates financial profit for the country which then spills over into the public health sector, improving the lives of the lowest social classes (Hopkins et al. 2010; Helble 2011). As argued by political leaders and medical tourism supporters, this industry has the potential to make a contribution to the development of health services, making new specialties and technologies available to the local population (Hopkins et al. 2010; Snyder et al. 2013).

In-depth research on the impact of medical tourism on the destination country has painted a different picture. Previous studies in India, Malaysia, and Thailand have indicated that the positive effects of medical tourism proclaimed in health policies are seldom present in practice (Alsharif et al. 2010). On the contrary, medical tourism tends to escalate the cost of health care for local populations (Saniotis 2007), draws scarce resources such as capital, technology, and personnel from public medical facilities (Chen and Flood 2013), and shifts the allocation of resources from primary to tertiary care (Alsharif et al. 2010).

Health care costs in popular medical tourism destinations such as India, Jordan, and China have steadily risen (Alsharif et al. 2010; Chen and Flood 2013; Saniotis 2007). The increase in demand for services by medical tourists allows clinical facilities to charge more (Snyder et al. 2013). This is certainly the case for private hospitals, 
but medical tourism has also influenced the costs and care available in public facilities as fee paying patients are often prioritised over patients entitled to free care (Pocock and Phua 2011). Furthermore, the quality of care available to medical tourists is not the same as that offered to local patients, as medical tourists can afford to pay for personalised attention, senior level clinical staff, and luxurious hospital rooms (Chen and Flood 2013). This issue raises serious questions about the principle of equity of care, while also shedding light on the existence of a 'dual' or 'two-tiered' health system (Chen and Flood 2013; Hazarika 2010: 249; Helble 2011: 70; Kassim 2009: 442).

The incentives offered by private hospitals and medical tourism companies have produced internal knowledge and skill drain, where medical professionals from public hospitals move into the private sector, and those from rural areas relocate to urban areas (Connell 2006; Kassim 2009; Helble 2011). As a consequence, a significant portion of the local population is left without medical coverage. Medical professionals leaving the public sector are often those in senior positions, thus affecting the level of medical expertise available to local patients (Chen and Flood 2013).

In some instances, the growing medical tourism industry has led to the expansion of tertiary care and a reduction in focus upon primary care (usually the care more widely and frequently used by the local population) (Helble 2011; Leahy 2008). While the expansion of tertiary care can improve the availability of medical technology, previous research has shown that the local population requiring access to specialised equipment is usually asked to pay (Heng Leng 2010). In addition, specialised personnel and equipment are often found in private hospitals in large urban areas, and thus are not always easy to access (Hazarika 2010).

In countries with strong public health systems and universal models of medical coverage, the expansion of the medical tourism industry poses particular challenges. According to Kassim, medical tourism can corrode 'the basis of national health care systems based on solidarity and the promotion of shared ethical values' (2009: 441). State-led initiatives to promote medical tourism send a contradictory message when health is portrayed as a free basic service at the national level, yet simultaneously viewed as a commodity for international medical tourists (Smith et al. 2009). Furthermore, government funding is often diverted into paying for services enjoyed by foreign medical tourists (Crooks et al. 2013).

When looking at the effects of medical tourism on the care provided to local populations, it is important to consider health care 
reforms and the ways in which models of care might have changed over time in the destination country. As Ormond has argued:

without negating the impact of 'medical tourism' on destinations, in framing it as an external 'innovation' or 'invasion', we risk not paying sufficient attention to the complex political contexts that have enabled 'medical tourism' and the selective harnessing of patient-consumer flows to flourish in particular places (2011: 256).

In other words, the medical tourism industry can be seen by government authorities in destination countries as a source of financial profit and an extension of local models of care seeking to privatise health services. However, in practice the degree to which these financial benefits improve the health and living conditions of the country as a whole will be shaped by the social, political, and economic processes taking place locally.

\section{Current health care challenges in Argentina}

Argentina's public investment in health care is one of the highest in Latin America, at 9.6\% of its Gross Domestic Product (GDP) in 2008 (Bello and Becerril-Montekio 2011). However, the country continues to face high infant and maternal mortality rates when compared to its regional counterparts, there are evident health inequalities across the country, and its health system operates under a fragmented and unsustainable model of care (Bello and Becerril-Montekio 2011; Stolkiner et al. 2011).

The Argentine health care system is divided in three main sectors: public, private, and social security. The public sector is organised at the municipal, provincial, and national levels, and provides coverage for approximately $35 \%$ of the population (Soriano et al. 2011: 730). The private sector provides services to $5-7 \%$ of the population through a series of pre-paid health maintenance organisations (HMOs) (Ibid.). The rest of the population receives care from the social security sector, a complex network of care providers, often administered by trade unions, and including some of the HMOs of the private sector (Stolkiner et al. 2011). These care providers implement a wide range of regulatory frameworks and vary in terms of financial administration, client characteristics, and available medical services (Stolkiner et al). Communication and coordination of care between the three sectors is poor and often leads to delays in services (Bello and Becerril-Montekio 2011). The Argentinian government has established a basic health benefits programme through its Programa Médico Obligatorio (PMO; Mandatory Medical Programme) to guarantee free access to medical 
attention and medication (over 370 generic medicines) and ensure that all health care providers maintain a standard level of care (Bello and Becerril-Montekio 2011; Bertranou 1999).

Current government initiatives seek to expand universal health coverage, but face profound regional inequalities in the distribution of medical facilities, equipment, and human resources (Kent Ranson et al. 2010). There are currently 4.1 hospital beds per 1000 people (a high number from a global perspective), with 53\% of these belonging to the public sector, $44 \%$ to the private sector, and $3 \%$ to the social security sector (Bello and Becerril-Montekio 2011:S102). Unfortunately, most of these beds are in large urban areas, and those in specialised centres are located in Buenos Aires (Maceira 2003). In the case of paediatric cancer treatment, for instance, it is estimated that $80 \%$ of all cases are treated within the public health system and $50 \%$ of these are treated in three specialised hospitals (Moreno et al. 2012). This centralisation of care forces over $40 \%$ of children to leave their place of origin and relocate for treatment (Moreno et al. 2009).

Even though Argentina has a high number of doctors - 38 per 10,000 people - they are not evenly distributed across the country. Most doctors reside and work in the province of Buenos Aires (which includes the capital and surrounding area), while extensive regions such as the north of the country (also one of the poorest areas) suffer from evident shortages of medical professionals (Williams et al. 2013). For instance, while in the city of Buenos Aires there is one doctor per 90 people, in Misiones, a northern province, there is only one doctor per 668 people (Abramzon 2005). Furthermore, while there are 38 doctors per 10,000 people in Argentina overall, there are only 3.8 nurses per 10,000 people (Stolkiner 2011).

Previous research has highlighted Argentina's 'hospital-centric' model of care, where emphasis is placed on the development of technologically advanced medical centres, the training of highly specialised medical professionals, and the centralisation of care (Stolkiner et al. 2011). Primary care, prevention strategies, the training of general practitioners, and establishment of communitybased clinical teams are often side-lined (Kent Ranson et al. 2010; Stolkiner et al. 2011). This model leaves a considerable percentage of the population without proper access to basic medical care.

\section{Medical tourism in Argentina}

Medical tourism is not a new phenomenon in Argentina, as it is a popular destination for patients seeking cosmetic surgery, dental 
work, and fertility treatment (Smith et al. 2009). It is estimated that between 8 and 10 thousand people travel to Argentina to undergo some sort of medical procedure (La Razón 2010). Patients choose Argentina because it has highly trained medical professionals, is considered 'an exotic tourist destination' (Balch 2006: 2), and contemporary medical procedures are considerably cheaper when compared to other destinations since the devaluation of the Argentine peso in 2002 (Nwosu-Hope 2010; Smith et al. 2009).

\section{Medical tourism for US and European patients}

Currently, governmental-private sector agreements are being established to attract patients from the United States and Europe. This new initiative, called Medicina Argentina (Argentina Healthcare), hopes to raise the number of foreign patients to 100,000 per year. This new strategy seeks to: (1) provide services to patients who might not be able to access them in their own countries due to high cost, unavailability, or long waiting lists, (2) increase Argentine tourism income, and (3) improve the quality of the medical services available to local populations (interview Gonzalez Prieto 2009). Medicina Argentina is directed by the Instituto Nacional de Promoción Turistica (INPROTUR; National Institute of Tourism Promotion), a dependency of the Ministry of Tourism, and it involves other government authorities such as the Cámara Argentina de Turismo (Argentina Chamber of Tourism) and the Cámara de Instituciones Argentinas para la Promoción de la Salud (Argentine Chamber of Institutions for Health Promotion). According to the director of INPROTUR, medical tourism is 'an initial pillar in the development of a product with great potential and can strengthen the growth of the tourism sector, which has consolidated itself over the years as a tool of development and inclusion for all Argentines' (Revista Gran Hotel Turismo 2014: 1).

Promotional material for this new strategy underscores the high quality of medical professionals in the country, and reminisces about the work of medical figures such as René Favaloro, Luis Federico Leloir, and Bernardo Houssay ${ }^{3}$ (Revista Gran Hotel Turismo 2014). Furthermore, advertisements in the form of press releases and feature articles often draw attention to an added quality of Argentine medical tourism:

[T] he possibility to visit natural wonders such as the Perito Moreno Glacier or the Iguazu Falls; visit the north of Argentina with its unique landscape such as the Quebrada de Humahuaca and Salinas Grandes; 
enjoy some of the best wine in the region of Cuyo at the base of the Cordillera de los Andes; or learn about the culture, tango and distinguished gastronomy of the country. (Revista Gran Hotel Turismo 2014: 1)

Viladrich and Baron-Faust, analysing the content of marketing announcements promoting Argentine medical tourism, have found that this country distinguishes itself from other medical tourism destinations by projecting the image of a "proto-European country that offers outstanding natural beauty and exceptional sophistication with top-tier cosmetic medicine' (2014: 118). This depiction of Argentine society allows medical tourism companies to create a feeling of 'cultural affinity' between medical tourists and medical providers (Viladrich and Baron-Faust 2014: 118).

\section{Medical tourism for neighbouring countries}

Even though Medicina Argentina was launched in 2011, Argentina has been welcoming foreign patients for years. Argentina's universal model of healthcare and open immigration policies make it a popular destination for people from neighbouring countries requiring free medical treatments. These medical tourists come from nearby countries such as Bolivia, Peru, and Paraguay. They are often from lowincome households and rural areas, and travel to Argentina seeking medical attention in public hospitals because they are unable to pay for services in their own countries (Ledesma 2010; Sala 2002; VindrolaPadros and Whiteford 2012).

The law on migration (law 25.871) guarantees all immigrants in Argentina free access to medical services under articles 6 and $8{ }^{4}$ Article 23 lists all categories of temporary residents acknowledged by the State and category 8 recognises individuals who are in Argentina to obtain medical treatment. ${ }^{5}$ Basically, the Argentine Migration Law indicates that documented and undocumented migrants in the country cannot be denied medical attention. Medical attention involves a wide range of services (not just emergency care) and, if the person requiring care is not residing legally in the country, it is the responsibility of medical personnel to inform them of the procedures required to change their legal status.

As Sala (2002) has indicated, it used to be customary for patients from Bolivia and Paraguay to cross the border and seek care in northern Argentine provinces such as Jujuy and Misiones. However, patients are also making their way to Buenos Aires (Sala 2002). 
A reason for this could be their search for specialised care, as hospitals in Buenos Aires have witnessed an increase of Bolivian and Paraguayan patients requesting treatment for chronic and often complex medical conditions (Ledesma 2010).

While patients from the United States and Europe are represented as 'visitors' and 'people needing to re-establish their health' (INPROTUR 2014; Revista Gran Hotel Turismo 2014: 1), Bolivian and Paraguayan migrants are portrayed by Argentine society as 'taking what is not theirs' (Caggiano 2005: 183). Cases of racism have been documented across the country where Bolivian and Paraguayan migrants are represented as 'darker' than Argentines (Clarin 2005, 2006: 1; Grimson 2006). Xenophobia takes on medical connotations when migrants from these countries are blamed for diseases such as dengue, cholera, and tuberculosis. Sala has argued that the association between 'foreigner-temporary worker-dirty and poor-disease carrier' is commonly used (Sala 2002: 27).

In addition to these incoming patients, Argentina already has a high rate of internal migration for treatment produced by its centralised model of care. Patients with complex conditions are often forced to relocate to Buenos Aires to seek medical attention from specialised staff or to access medical technology. Constant flows of patients from neighbouring countries and Argentine provinces add another layer to the analysis of medical tourism in Argentina. As a large volume of medical tourists from the US and Europe are lured by the State to buy Argentine medical services, the health system will have to adapt to fulfil the demand for health and social services of three separate groups of mobile patients (patients from the US and Europe, patients from neighbouring countries, and local patients). As discussed in the next sections, this has implications for healthcare professionals and the quality of care delivered in all sectors of the health system.

\section{A cautionary tale}

The director of INPROTUR recently launched a nation-wide promotion of medical tourism to show what Argentina has to offer (INPROTUR 2014: 2). The Chamber of Argentine Institutions for the Promotion of Health was created and press releases published to inform the general public of this new government strategy (BaireSalud 2011). However, little information has been made available on assessments carried out by government authorities to ensure that the current health care infrastructure has the capacity to treat and house 
the targeted 100,000 patients per year without compromising the services available to the local population.

\section{Medical tourism benefits}

As mentioned earlier, an important part of the advertisement of Medicina Argentina has centred on the financial benefits it will bring to the country in the form of income and availability of novel medical technologies for local populations. This argument has been used frequently in other medical tourism destinations (Connell 2006; Hopkins et al. 2010). Nevertheless, studies measuring the actual effects of medical tourism on local economies have found that even though medical tourism represents a 60 billion dollar industry (Eissler et al. 2013), this money is seldom used to improve the services available to the populations in the destination countries (Chen and Flood 2013; Connell 2011).

The principle of trickle-down economics sounds good in theory, but if it is to be put into practice, it requires: (1) a system for collecting taxes from medical tourism, and (2) a system for redistributing the funds obtained from taxation back into the public system (Blouin 2010; Hopkins et al. 2010; Snyder et al. 2013). As several authors have indicated, this entails direct political action and the transformation of macroeconomic redistributive policies (Chen and Flood 2013; Helble 2011; Hopkins et al. 2010; Snyder et al. 2013). To date, Argentina has not produced a definite set of measures designed to guarantee that the income generated by the medical tourism industry will be fed into the public sector.

The other potential benefit of increasing medical tourists lies in access to new medical technologies (Ramirez de Arellano 2007). This argument has also been used before by other governments, yet local populations in other countries have not gained the advantages that were initially promised (Burkett 2007). Most of the time these new medical technologies have been centralised in a few large cities (Chen and Flood 2013: 289) and the local population has been charged high fees for their use (Heng Leng 2010). In the case of Argentina, new technology brought into the country to deal with the demand of foreign patients will be located in the institutions that form part of the Chamber of Argentine Institutions for the Promotion of Health, as these actors have formed part of the government's strategy for promoting medical tourism. These include: Hospital Italiano, Hospital Alemán, Hospital Austral, Instituto Cardiovascular de Buenos Aires, 
Clínica Nano, Clínica Robles, Dental House, FLENI, and Calista Center. ${ }^{6}$ Not only are these medical facilities part of the private sector, but they are also located in Buenos Aires.

Public authorities will need to establish and enforce clear legal frameworks to guarantee free or low cost access to these technologies for the local population in order to extend the benefits of the medical tourism industry beyond the private sector. The question that still remains is how will access be ensured across the country? If mechanisms are not put in place to deal with this centralisation of new technology, the medical tourism initiative will continue to reproduce the already existing inequalities in access to medical services.

\section{Impact on human resources}

New technology will be made available, but the initiative does not provide details on the ways in which medical professionals will be organised to deal with patient demand. Previous studies on the impact of medical tourism on destination countries have shed light on cases of internal brain drain, where medical professionals are lured from the public to the private sector, thus affecting the care received by the poorest sector of the local population (Hazarika 2010; Pachanee and Wibulpolprasert 2006).

As was mentioned earlier, national statistics demonstrate that Argentina does not have a deficit of specialised doctors, indicating that it could potentially deal with a certain degree of internal brain drain. However, the number of doctors should be looked at cautiously as it obfuscates the current working situation of many medical professionals in the country. For example, these statistics do not allow us to see: (1) the number of doctors who split their time between public and private health sectors, and might also teach in universities, (2) the distribution of doctors across different specialties, and (3) the actual working conditions of medical professionals in the public sector (available resources, opportunities for career development, rates of stress and burn-out, and so on).

Even though the Argentine health care system is divided into three main sectors, the lines that divide them are often not clear. This is evident when we look at the ways in which medical professionals provide services, as a doctor might be based in a public hospital, but also hold consultations in the private sector (for another international example, see Hsiao 2008). This dual appointment allows doctors to deal with low salaries in the public sector. In an analysis of cardiology 
residencies in Argentina, Grancelli (2011:164) indicates that $63 \%$ of the residents need another job and generally look for posts in other medical centres (see also Waldman et al. 2009).

A growing medical tourism industry would certainly provide incentives to bring medical professionals into the private sector, leading to their abandonment of the public sector and increasing the workload of remaining professionals who are already experiencing burden. As Grancelli (2011) mentions, some medical professionals in the public sector do not receive remuneration for their work (they are hired ad honorem, or under honorary contracts), but they contribute to the care delivered at public institutions because they are committed to the idea of universal health coverage, they see it as an educational experience, or they want a public hospital affiliation because of the prestige associated with specific public hospitals across the country. This honorary model of work is also present in public education institutions where many medical professionals teach. If stronger demands are placed on the time of these professionals due to the massive entry of medical tourists, it is uncertain how their honorary contributions will be affected.

The rate of qualified doctors in the country does not reflect their distribution across different medical specialties. Medical training in Argentina has been oriented towards high, and often unstandardised and unregulated, levels of specialisation. During the 1990s there were 240 recognised medical specialties in Argentina, while in other parts of the world this number ranged from 50 to 70 (Borrell Bentz 2005: 112). Furthermore, most of the specialties do not respond to the actual health care needs of the population (Ibid: 112). This situation is felt at the level of primary care which is often not given the same value as other medical areas (Stolkiner et al. 2011: 2813), and is not included as an essential part of medical training (Borrell Bentz 2005).

Even though the number of doctors is high, Argentina is experiencing a tangible shortage of nursing staff (Kent Ranson et al. 2010); an issue that could be exacerbated by the influx of new patients and affect the care of the local population. Assessments of this situation have pointed to the need for a rapid programme capable of promoting nursing training and the insertion of qualified nurses into the public health sector (Abramzon 2005; Gonzalez et al. 2010). The working conditions of nurses in the public sector also need to be improved to prevent them from moving into the private sector. Currently, nurses encounter a highly stressful working environment characterised by an excessive workload, lack of autonomy for 
making decisions, lack of stimuli and opportunities for professional development, double shifts and long working hours, and low salaries (Diaz Echenique et al. 2010).

Stress and burn-out have also been documented among doctors and medical students (Dahlin et al. 2013; Doval 2007). In a study on cardiology residents, Waldman et al. (2009: 298) found that $80.2 \%$ experienced some level of burnout and $71.7 \%$ experienced a high level of emotional exhaustion. Manrique (2006) found a similar situation among surgeons who felt their specialty did not receive appropriate recognition, salaries were low, and their work was constantly subjected to legal threats. The working conditions of medical staff need to be taken into consideration when exploring initiatives, such as Medicina Argentina, that could create an even greater demand on their time and effort.

\section{The regulation of medical tourism}

Another important issue to consider is the current state of medical tourism regulation in Argentina. This concerns the accreditation of institutions providing care to foreign patients, the registration of individuals entering the country to obtain medical treatment (place of origin, length of stay, type of treatment), and the monitoring and persecution of cases of malpractice. Tourism for fertility treatments is common in Argentina, but in their review of fertility clinics offering assisted reproductive technologies to foreign patients, Smith et al. (2009) found that clinic accreditation was voluntary and there was no formal legislation or regulatory body to monitor the quality of the procedures. According to these authors, "non-accredited clinics have total discretion over how to run their clinics and which services to offer, and they are free from official oversight' (Smith et al. 2009: 66).

Lack of accreditation can also be linked to lack of accountability if procedures go wrong. As Smith et al. (2009) have indicated, in non-accredited facilities, the doctor's responsibility ends when the patient leaves the clinic, and follow-up care is not always considered a part of the treatment sought abroad. This is an important issue to consider because previous research in other medical tourism destinations has pointed to multiple cases of postoperative or postprocedure complications and, in some instances, antibiotic-resistant infections that must be dealt with by medical staff in the tourists' country of origin when they return (Connell 2013; Crooks et al. 2013; Hall and James 2011). 


\section{Ethical issues at stake}

The 'new' medical tourism industry in Argentina brings to light existing contradictions and social tensions regarding health equity. The State publicly defends a universal model of health care, but its current infrastructure and model of care create a vicious circle of health inequality where the poorest and most marginalised sectors of Argentine society suffer the direst consequences. The medical tourism industry reproduces these inequalities by juxtaposing different types of medical tourists: patients from the US and Europe, and patients from neighbouring countries (mainly Bolivia and Paraguay).

These different groups of medical tourists have coexisted for decades, but as Argentina puts forth a new initiative to bring in ten times the number of medical tourists from the US and Europe per year, health inequalities are likely to worsen. The 'new' medical tourism industry will need medical professionals and infrastructure to grow, and these will probably come from existing resources in the public and private sector. A dual or 'two-tiered' health care model documented in other medical tourism destinations (Connell 2013; Lunt and Carrera 2010; Ramirez de Arellano 2007) could emerge, where medical tourists from the US and Europe receive care in stateof-the art facilities with highly qualified personnel, and medical tourists from neighbouring countries and the local population receive suboptimal care in overburdened clinics and hospitals. The care wealthier Argentines receive in the private sector could also be affected as certain hospital areas might become restricted to foreign patients and medical resources might need to be diverted to deal with their care needs. This has been a common trend seen in other medical tourism destinations such as Thailand and India where hospital wings have been set aside exclusively for the care of international medical tourists (Mary 2014).

Another important issue is the establishment of frameworks to regulate the medical tourism industry. This will entail the establishment of national accreditation guidelines and the adherence to international guidelines of medical care (Connell 2013), the development of legal channels to deal with cases of malpractice in a timely manner, and the creation of a system of taxation and redistribution where the financial gains of the medical tourism industry are invested in the public sector (Blouin 2010; Hopkins et al. 2010; Snyder et al. 2013). If these measures are not put in place, the medical tourism industry could sustain uncontrolled growth and fail to improve the living conditions of the local population. 


\section{Conclusion}

In this article I have attempted to present a complex picture of medical tourism from the perspective of the destination country. This growing industry needs to be understood in particular social, political, geographic, and economic contexts. It needs to be studied in relation to local health care models and policies. The case of Argentina is interesting in the sense that it allows us to see the process behind the creation of a 'new' medical tourism destination in a context where the health care needs of all sectors of society are not guaranteed. The relative novelty of Medicina Argentina, the lack of public dissemination of plans for its national implementation, and the lack of academic research on these topics make ascertaining the effects of this growing industry on the care provided to local populations extremely difficult. This lack of information should not deter us, however, from exploring the potential issues that could emerge if Medicina Argentina is implemented to its fullest extent. The current problems faced by the Argentine health care system and the past experiences of other medical tourism destinations highlight the need to exert caution and tread lightly. A research agenda needs to be developed to grasp this process in its entirety. Future research could focus on the experiences of care of different groups of medical tourists, the perspectives of medical professionals working in different areas of the health system, and the creation of mechanisms to invest the profit of the medical tourism industry in the public sector.

\section{Notes}

1. I have joined other authors (Sobo 2009; Whittaker et al. 2010) in highlighting the problems associated with the concept of 'medical tourism' and have spoken in favour of using the concepts of 'medical travel' and 'micro-mobility' to account for a wider range of travel needs, experiences, and trajectories (Vindrola-Padros and Whiteford 2012; Vindrola-Padros and Johnson in press). However in this article I use medical tourism due to the following reasons: 1) to be consistent with the term that is used throughout the special issue, 2) to frame the industry in the same light as the documents describing Medicina Argentina. Even though I use the term 'medical tourism', I believe the way in which this process is presented in the article responds to the limitations I have highlighted in previous publications. I have made the attempt to present it here as a complex, multidimensional, and individualised process.

2. When the term medical tourism is used in this article, it does not include transplant tourism as this industry has particular characteristics and raises unique ethical concerns (Bagheri 2010).

3. René Favaloro was a preeminent cardiovascular surgeon. Luis Federico Leloir received a Nobel Prize for Chemistry in 1970 and Bernardo Houssay shared the Nobel Prize for Physiology or Medicine in 1947 (Krapp 1998). 


\section{Medical Tourism in Argentina}

4. 'Art. 6. The State under all of its jurisdictions, will assure the equal access of immigrants and their families, under the same conditions of protection and rights as nationals, to social services, public estates, health, education, justice, work, employment and social security. [...]

Art. 8. The right to health, social assistance, or sanitary attention cannot be negated or restricted for foreigners regardless of their migratory status. The authorities of the sanitary establishments must provide orientation and information regarding the necessary paperwork in order to resolve migration irregularities' (Senado y Cámara de Diputados de la Nación Argentina 2011).

5. 'h) Patients in medical treatment: to deal with health problems in public or private facilities, have the authorisation to remain for a year, with the option of extension, with multiple entries and exits. In case of minors, disabled, or ill individuals who due to their pathology must remain with caretakers, this authorisation will be made extensive to the direct family members, legal representatives or healers' (Senado y Cámara de Diputados de la Nación Argentina 2011).

6. The current list of medical providers advertised on the Medicina Argentina website include: Hospital Alemán, Hospital Austral, ICBA, Hospital Británico, Clínica Bazterrica, Swiss Medical Center, and Sanatorio Allende. These are all private medical facilities and most of them provide care in Buenos Aires (with the exception of Swiss Medical Center which has medical centres distributed across the country) (Medicina Argentina 2014).

\section{References}

Abramzon, Monica (2005), Argentina: Recursos Humanos en Salud en 2004, Buenos Aires, Argentina: OPS/OMS.

Alsharif, Mohd Jamal, Ronald Labonte, and Zuxun Lu (2010), 'Patients beyond borders: A study of medical tourists in four countries', Global Social Policy, 10, pp. 315-335.

Balch, Oliver (2006), 'Buenos Aires or bust', The Guardian, Retrieved March 13, 2014 from http://www.theguardian.com/business/2006/oct/24/argentina.travelnews

Bagheri, Alireza (2010), 'Global health regulations should distinguish between medical tourism and transplant tourism', Global Social Policy, 10, pp. 295-297.

BaireSalud (2011), 'Nació la Cámara de Instituciones Argentinas para la Promoción de la Salud', Accessed May 14, 2014, http://www.baires-salud.com.ar/novedades-27/ nacio-la-camara-de-instituciones-argentinas-para-la-promocion-de-la-salud-1081.html

Bello, Mariana and Becerril-Montekio, Victor (2011), 'Sistema de salud en Argentina', Salud Pública de México, 53:S2, pp. S96-S108.

Bertranou, Fabio (1999), 'Are market-oriented health insurance reforms possible in Latin America? The Cases of Argentina, Chile and Colombia', Health Policy, 47, pp. 19-36.

Blouin, Chantal (2010), 'Trade in health services: Can it improve access to health care for poor people?' Global Social Policy, 10, pp. 293-295.

Borrell Bentz, Maria Rosa (2005), La educación médica de posgrado en Argentina: El desafio de una nueva practica educativa, Buenos Aires, Argentina: OPS/OMS.

Burkett, Levi (2007), 'Medical tourism: Concerns, benefits, and the American legal perspective', The Journal of Legal Medicine, 28, pp. 223-245.

Caggiano, Sergio (2005), Lo Que no Entra en el Crisol: Inmigración Boliviana, Comunicación Intercultural y Procesos Identitarios, Buenos Aires, Argentina: Prometeo Libros. 


\section{Somatechnics}

Chen, Y Brandon, Colleen Flood (2013), 'Medical tourism's impact on health care equity and access in low-and middle-income countries: Making the case for regulation', Iournal of Law. Medicine, and Ethics, 41:1, pp. 286-300.

Clarin (July 27, 2005), Racismo en Argentina: Pocos inmigrantes lo denuncian, muchos lo sufren, Retrieved December 2011, http://edant.clarin.com/diario/2005/07/27/ conexiones/t-1021627.htm

Clarin (July 22, 2006), Denuncia por discriminación en Escobar, Retrieved December 2011, http://edant.clarin.com/diario/2006/07/22/sociedad/s-05401.htm

Connell, John (2006), 'Medical tourism: Sea, sun, sand and ...surgery', $\underline{\text { Tourism }}$ Management, 27:6, pp. 1093-1100.

Connell, John (2011), 'A new inequality? Privatisation, urban bias, migration and medical tourism', Asia Pacific Viewpoint, 52:3, pp. 260-271.

Connell, John (2013), 'Contemporary medical tourism: Conceptualisation, culture and commodification', Tourism Management, 34, pp. 1-13.

Crooks, Valorie, Leigh Turner, Glenn Cohen, Janet Bristeir, Jeremy Snyder, Victoria Casey, and Rebecca Whitmore (2013), 'Ethical and legal implications for the risks of medical tourism for patients: A qualitative study of Canadian health and safety representatives' perspectives', $\underline{B M I}$ Open, 3:2, pp. 1-8.

Dahlin, M, A Ursberg, and B Runeson (2013), 'A comparative study of stress and mental health among Argentinean and Swedish medical students', The Internet Journal of Medical Education, 1, pp. 1-12.

Diaz, Echenique, Maria Sara, Maria Ines Stimolo, and Norma Patricia Caro (2010), 'Satisfacción laboral y síndrome de desgaste laboral en enfermeros de hospitales públicos Córdoba-Argentina', Medicina y Seguridad del Trabajo, 56:218, pp. 22-38.

Doval, H. (2007), 'Malestar en la medicina. Insatisfacción y descontento en los médicos', Revista Argentina de Cardiología, 76, pp. 417-422.

Eissler, Lee Ann and John Casken (2013), 'Seeking health care through international medical tourism', Journal of Nursing Scholarship, 45:2, pp. 177-184.

Gonzalez, Albertina, Claudia Castro, Silvana Moreira, Sandra Cerino, Maria del Valle Correa Rojas, Ramona Atzemian, Graciela Patrito, Francisco Castillo Nunez, and Marcela Rojas (2010), 'Situación de la formación en las escuelas de enfermería terciarias no universitarias de la República Argentina', Revista Argentina de Salud Pública, 1(5), pp. 28-32.

Grancelli, Hugo (2011), 'Cardiology residencies in Argentina. Current realities and challenges', Argentine Journal of Cardiology, pp. 164-165.

Grimson, A. (2006), 'Nuevas xenofobias, nuevas políticas étnicas en la Argentina', in A. Grimson, and E. Jelin (eds.), Migraciones regionales hacia la Argentina: Diferencia, desigualdad y derechos, Buenos Aires, Argentina: Prometeo Libros, pp. 69-97.

Hall, C. M. and M. James (2011), 'Medical tourism: emerging biosecurity and nosocomial issues', Tourism Review, 66, pp. 118-126.

Hazarika, Indrajit (2010), 'Medical tourism: Its potential impact on the health workforce and health systems in India', Health Policy and Planning, 25, pp. 248-251.

Helble, Matthias (2011), 'The movement of patients across borders: Challenges and opportunities for public health', Bulletin World Health Organization, 89, pp. $68-72$.

Heng Leng, Chee (2010), 'Medical tourism and the state in Malaysia and Singapore', Global Social Policy, 10, pp. 336-357. 


\section{Medical Tourism in Argentina}

Heng Leng, Chee and Andrea Whittaker (2010), 'Guest editors' introduction to the special issue: Why is medical travel of concern to global social policy?', Global Social Policy, 10, pp. 287-291.

Hopkins, Laura, Ronald Labonte, Vivien Runnels, and Corinne Packer (2010), 'Medical tourism today: What is the state of existing knowledge?', Iournal of Public Health Policy, 31:2, pp. 185-198.

Hsiao, William (2008), 'When incentives and professionalism collide', Health Affairs, 27:4, pp. 949-951.

INPROTUR (March 8, 2014), 'Argentina promociona el turismo médico', Retrieved on May 14, 2014, from http://www.argentina.travel/es/press/argentina-promociona-elturismo-medico/658\#.U3oHMyjnMrU

Kassim, Puteri (2009), 'Medicine beyond Borders: The legal and ethical challenges', Med Law, 28, pp. 439-450.

Kent Ranson, Michael, Mickey Chopra, Salla Atkins, Mario Roberto Dal Poz, and Sara Bennett (2010), 'Priorities for research into human resources for health in lowand middle-income countries', Bulletin World Health Organization, 88, pp. 435-443.

Krapp, Kristine M. (1998) Notable Twentieth Century Scientists: Supplement, Volume 5. Gale.

La Razón (2010), 'Argentina, destino elegido para el turismo médico', Retrieved on March 11, 2014 from http://www.larazon.com.ar/actualidad/Argentina-destinoelegido-turismo-medico_0_175200014.html

Leahy, A. L. (2008), 'Medical tourism: The impact of travel to foreign countries for healthcare', $\underline{\text { Surgeon, }}$ 6:5, pp. 260-261.

Ledesma, F. (2010), 'Extranjeros No Residentes y Cobertura de Salud: Un Conflicto entre Principios', Medicina Infantil, 17:3, pp. 282-286.

Lunt, Neil and Percivil Carrera (2010), 'Medical tourism: Assessing the evidence on treatment abroad', Maturitas, 66, pp. 27-32.

Maceira, Daniel (2003), Descentralización y equidad en el sistema de salud Argentino. Buenos Aires, Argentina: CEDES.

Manrique, J. L. (2006), 'Relación entre la calidad de vida del cirujano y su actuación profesional', Revista Argentina de Cirugía, 91, pp. 77-153.

Mary, R. S. S. (2014), 'Medical tourism in Asia-An Overview', Scholarsworld, 2:2, pp. 131-136.

Medical Tourism Magazine (2009), 'Interview with Guillermo Gonzalez Prieto', retrieved November 1, 2011, http://www.medicaltourismmag.com/video/drguillermo-gonzalez-prieto.html

Medicina Argentina (2014), 'Medicina Argentina/Argentina Healthcare', Retrieved on May 20, 2014, from http://www.argentinahealthcare.org/index.html

Moreno F. D. V., Abriata G., Loria D., et al. (2012), Hospital-based pediatric oncology registry (Registro Oncopediátrico Hospitalario Argentino, ROHA INC). Incidence 2000-2009, survival 2000-2007, mortality trends 1997-2010. Buenos Aires, Argentina: In Edition.

Moreno, F., Schvartzman E., Scopinaro M., et al. (2009), Hospital-based pediatric oncology registry (Registro Oncopediátrico Hospitalario Argentino, ROHA). Results 2000-2008, Buenos Aires, Argentina: ROHA.

Nwosu-Hope, V. (2010), 'The new medical tourism mecca', retrieved on March 13, 2014 from http://www.argentinaindependent.com/socialissues/urbanlife/the-newmedical-tourism-mecca/

Ormond, Meghann (2011), 'Shifting subjects of health-care: Placing 'medical tourism' in the context of Malaysian domestic health-care reform', Asia Pacific Viewpoint, 52:3, pp. 247-259. 


\section{Somatechnics}

Pachanee, Cha-aim and Suwit Wibulpolprasert (2006), 'Incoherent policies on universal coverage of health insurance and promotion of international trade in health services in Thailand', Health Policy and Planning, 21:4, pp. 310-318.

Pocock, Nicola and Kai Hong Phua (2011), 'Medical tourism and policy implications for health systems: A conceptual framework from a comparative study of Thailand, Singapore and Malaysia', Globalization and Health, 7, pp. 1-12.

Ramirez de Arellano, Annette (2007), 'Patients without borders: The emergence of medical tourism', International Journal of Health Services, 37:1, pp. 193-198.

Revista Gran Hotel Turismo (2014), Argentina promociona el turismo medico, retrieved September 22, 2014 from http://www.revistagranhotel.com/argentinapromociona-el-turismo-medico/

Sala, Gabriela (2002), 'Entre el temor y la exclusión: acciones de salud dirigidas a migrantes bolivianos y acciones sanitarias en la frontera norte de Argentina', paper presented at the XIII Encontro da Asociação Brasileira de Estudos Populacionais, Minas Gerais, Brazil.

Saniotis, Arthur (2007), 'Changing ethics in medical practice: a Thai perspective', Indian Journal of Medical Ethics, 4:1, pp. 24-25.

Senado y Cámara de Diputados de la Nación Argentina (2011), Ley de Migraciones-Ley 25871, retrieved December 2011, from http://www.gparlamentario.org/spip/ spip.php?article177

Smith, Elise, Jason Behrmann, Carolina Martin, and Bryn Williams-Jones (2009), 'Reproductive tourism in Argentina: Clinic accreditation and its implications for consumers, health professionals, and policy makers', Developing World Bioethics, 10:2, pp. 59-69.

Snyder, Jeremy, Valorie A Crooks, Leigh Turner, and Rory Johnston (2013), 'Understanding the impacts of medical tourism on health human resources in Barbados: a prospective, qualitative study of stakeholder perceptions', International Iournal of Equity in Health, 12, pp. 2-11.

Sobo, Elisa (2009), 'Medical travel: What it means, why it matters', Medical Anthropology, 28, pp. 326-335.

Soriano, Enrique, Rosa, Javier, Velozo, Edson, Schpilberg, Monica, Imamura, Patricia, Diaz, Jorge, and Catoggio, Luis (2011), 'Incidence and prevalence of psoriatic arthritis in Buenos Aires, Argentina: a 6-year health management organization-based study', Rheumatology 50, pp. 729-734.

Stolkiner, Alicia, Comes, Yamila, and Garbus, Pamela (2011), 'Alcances y potencialidades de la Atencion Primaria de la Salud en Argentina', Ciencia y Saude Colectiva, 16:6, pp. 2807-2816.

Viladrich, Anahi and Baron-Faust, Rita (2014), 'Medical tourism in tango paradise: The internet branding of cosmetic surgery in Argentina', Annals of Tourism Research, 45, pp. 116-131.

Vindrola-Padros, Cecilia and Linda M. Whiteford (2012), 'The search for medical technologies abroad: The case of medical travel and pediatric oncology treatment in Argentina', Technology and Innovation, 14, pp. 25-38.

Vindrola-Padros, Cecilia and Ginger, A. Johnson (in press), 'Children seeking health care: International perspectives on children's use of mobility to obtain health services', in A. White, C. Ni Laoire, and T. Skelton (eds), Movement, Mobilities and Journeys, Geographies of Children and Young People Series, Vol. 6, Springer.

Waldman, Silvina, Juan Cruz Lopez Diez, Hernan Cohen Arazi, Bruno Linetzky, Salvador Guinojan, and Hugo Grancelli (2009), 'Burnout, Perceived Stress, and 


\section{Medical Tourism in Argentina}

Depression among Cardiology Residents in Argentina', Academic Psychiatry, 33:4, pp. 296-301.

Whittaker, Andrea, Manderson, Lenore, and Elizabeth Cartwright (2010), 'Patients without Borders: Understanding Medical Travel', Medical Anthropology, 29, pp. 336-343.

Williams, G., et al. (2013), Médicos en Argentina. Red Federal de Registros de Profesionales de la Salud, Observatorio Federal de Recursos Humanos en Salud, Ministerio de Salud de la Nación, Argentina. 